\title{
Surgical drainage vs conservative treatment of odontogenic cellulitis in pediatric
}

\section{patients: A systematic review}

\section{Drenagem cirúrgica vs tratamento conservador da celulite odontogênica em pacientes pediátricos:}

\section{Uma revisão sistemática}

\author{
Drenaje quirúrgico versus tratamiento conservador de la celulitis odontogénica en pacientes \\ pediátricos: Una revisión sistemática
}

\begin{abstract}
The aim of this study was to compare the efficacy of two different treatment of odontogenic cellulitis in pediatric patients: conservative treatment (just intravenous antibiotic administration and tooth root treatment or tooth extraction) and surgical treatment (intravenous antibiotic administration, incision, drainage and tooth root treatment or tooth extraction). The search strategy was conducted based on the model of systematic review adopted by PRISMA guidelines. The search strategy included: Pubmed/MEDLINE, Web of Science, Scopus and Cochrane Library databases seeking clinical trials with, unless, ten pediatric patients, in English and available on-line. The key-words used in the screening were "Infection Control, Dental and Cellulitis OR odontogenic infection and cellulitis". A total of 404 studies were obtained and the selection of manuscripts was performed based on the defined inclusion and exclusion criteria and four manuscripts were according with review. It was verified that the surgeons of these studies commonly choose the conservative treatment, varying the adherence rate between $75 \%$ and $95.2 \%$ and no complications were associated with this treatment. Likewise, $75 \%$ of the author support the conservative treatment. The conservative treatment of cellulitis in pediatric patients, presents efficacy without having to submit the patient to surgical drainage.
\end{abstract}

Keywords: Infection control, dental; Cellulitis; Pediatrics. 


\begin{abstract}
Resumo
O objetivo deste estudo foi comparar a eficácia de dois tratamentos diferentes de celulite odontogênica em pacientes pediátricos: tratamento conservador (apenas administração intravenosa de antibióticos e tratamento da raiz ou extração dentária) e tratamento cirúrgico (administração intravenosa de antibióticos, incisão, drenagem e raiz dentária tratamento ou extração dentária). A estratégia de busca foi realizada com base no modelo de revisão sistemática adotado pelas diretrizes do PRISMA. A estratégia de busca incluiu: bases de dados Pubmed / MEDLINE, Web of Science, Scopus e Cochrane Library que buscam ensaios clínicos com, a menos que dez pacientes pediátricos, em inglês e disponíveis on-line. As palavras-chave utilizadas na triagem foram "Controle de Infecção, Dentária e Celulite OU infecção odontogênica e celulite". Foram obtidos 404 estudos e a seleção dos manuscritos foi realizada com base nos critérios de inclusão e exclusão definidos e quatro manuscritos estavam de acordo com a revisão. Verificou-se que os cirurgiões desses estudos comumente optam pelo tratamento conservador, variando a taxa de adesão entre $75 \%$ e $95,2 \%$ e não houve complicações associadas a este tratamento. Da mesma forma, $75 \%$ do autor apóia o tratamento conservador. $\mathrm{O}$ tratamento conservador da celulite em pacientes pediátricos, apresenta eficácia sem a necessidade de submeter o paciente à drenagem cirúrgica.
\end{abstract}

Palavras-chave: Controle de infecções dentárias; Celulite (Flegmão); Pediatria.

\title{
Resumen
}

El objetivo de este estudio fue comparar la eficacia de dos tratamientos diferentes de la celulitis odontogénica en pacientes pediátricos: tratamiento conservador (solo administración de antibióticos por vía intravenosa y tratamiento de la raíz del diente o extracción del diente) y tratamiento quirúrgico (administración de antibiótico por vía intravenosa, incisión, drenaje y raíz del diente). tratamiento o extracción de dientes). La estrategia de búsqueda se realizó con base en el modelo de revisión sistemática adoptado por las guías PRISMA. La estrategia de búsqueda incluyó: bases de datos de Pubmed / MEDLINE, Web of Science, Scopus y Cochrane Library que buscaban ensayos clínicos con, a menos, diez pacientes pediátricos, en inglés y disponibles en línea. Las palabras clave utilizadas en el cribado fueron "Control de Infecciones, Celulitis y Dentales O infección y celulitis odontogénica". Se obtuvieron un total de 404 estudios y la selección de manuscritos se realizó en base a los criterios de inclusión y exclusión definidos y cuatro manuscritos fueron de acuerdo con la revisión. Se verificó que los cirujanos de estos estudios optan comúnmente por el tratamiento conservador, variando la tasa de adherencia entre el $75 \%$ y el $95,2 \%$ y no se asociaron complicaciones a este tratamiento. Asimismo, el 75\% del autor apoya el tratamiento conservador. El tratamiento conservador de la celulitis en pacientes pediátricos, presenta eficacia sin tener que someter al paciente a drenaje quirúrgico.

Palabras clave: Control de infección dental; Celulitis (Flemón); Pediatría.

\section{Introduction}

Odontogenic cellulitis is an infection arising from the dentition and its adjacent supporting periodontal structure and if treatment is delayed or administered improperly, it can spread to the face, neck, brain, orbital structures, mediastinum or systemically leading to sepsis. Most of orofacial odontogenic infections originate from necrotic pulps, infected periodontal pockets, or partially erupted teeth (Chowet al., 1978; Heimdahl \& Nord, 1983).

With now widely available antibiotics, better diagnostic techniques and early surgery, the mortality rate has decreased significantly over the years. Early and correct diagnosis of the true source of infection and definitive treatment of odontogenic cellulitis as soon as possible after admission may reduce the morbidity (Unkel et al., 1997).

Although, is necessary to differentiate two stages of odontogenic infection: Cellulitis and Abscess. Cellulitis is a stage of infection what overpass the periosteum and permeate to soft tissues spaces. It is a diffuse, acute, rapidly and progressive condition without defined limits which tends not to form pus and presenting mainly aerobic bacteria. If left untreated, cellulitis will evolve to an abscess or still spreading to the soft tissues and may evolve to a Ludwig's angina, cerebral abscess or sepsis. Phlegmon is another term usually used to designate Cellulitis. Abscess is the next stage of cellulitis. It is a chronic, localized, small, well circumscribed and fluctuant stage of infection which tends to form pus and presenting mainly anaerobic bacteria (Moghimi et al., 2013; Peterson, 2003; Shanti et al., 2011).

Different clinical response of infection is expected according the age of the patient. Likewise, a different antibiotic response is age-related. Prabhash et al. (2014) found that antibiotic resistance among higher age groups is higher when compared to lower age groups. Therefore, if clinical and drug responses are different to pediatric patient compared with adults, 
and children seen be better responsive to antibiotics, then what should we expect of usually modalities of treatment of odontogenic cellulitis in pediatric patients?

Thus, the aim of this systematic review is compare the efficacy of two different treatment in pediatric patients with odontogenic cellulitis: conservative treatment (just intravenous antibiotic administration and tooth root treatment or tooth extraction) and the surgical treatment (intravenous antibiotic administration, incision, drainage and tooth root treatment or tooth extraction).

\section{Methodology}

\section{Registry Protocol}

The search strategy was conducted based on the model of systematic review adopted by PRISMA guidelines (Moher et al., 2009). This review was registered in PROSPERO international data base of systematic reviews (CRD 42016048479).

\section{Search strategy and selection of studies}

The PICO question adopted was: "Is the conservative treatment as effective as surgical treatment to odontogenic cellulitis in pediatric patients?". It was used the Population, Interventional, Control and Outcomes (PICO) format to define an issue in comparative clinical studies involving pediatric patients with facial odontogenic cellulitis (P) undergoing to drainage (I) or not (conservative treatment) (C) and compare the efficacy of these treatments in this kind of patient $(\mathrm{O})$.

To perform the search strategy it was adopted: the Pubmed/MEDLINE, Web of Science, Scopus and Cochrane Library databases seeking relevant studies being clinical trials with, unless, ten pediatric patients, in English and available online. The searches were carried out by two independent reviewers (A.H.O and C.A.A.L) for possible inclusion in the review. The key-words used in the screening were "Infection Control, Dental and Cellulitis OR odontogenic infection and cellulitis". Firstly were obtained 277 articles from the "PubMed (MEDLINE)", 85 articles from "Web of Science", 24 articles from the Scopus and 18 articles in "Cochrane" basis. The selection of manuscripts was performed based on the defined inclusion and exclusion criteria and, at the search end; four manuscripts were according with review (Fig. 1). 
Figure 1- Flowchart representing the search strategy.

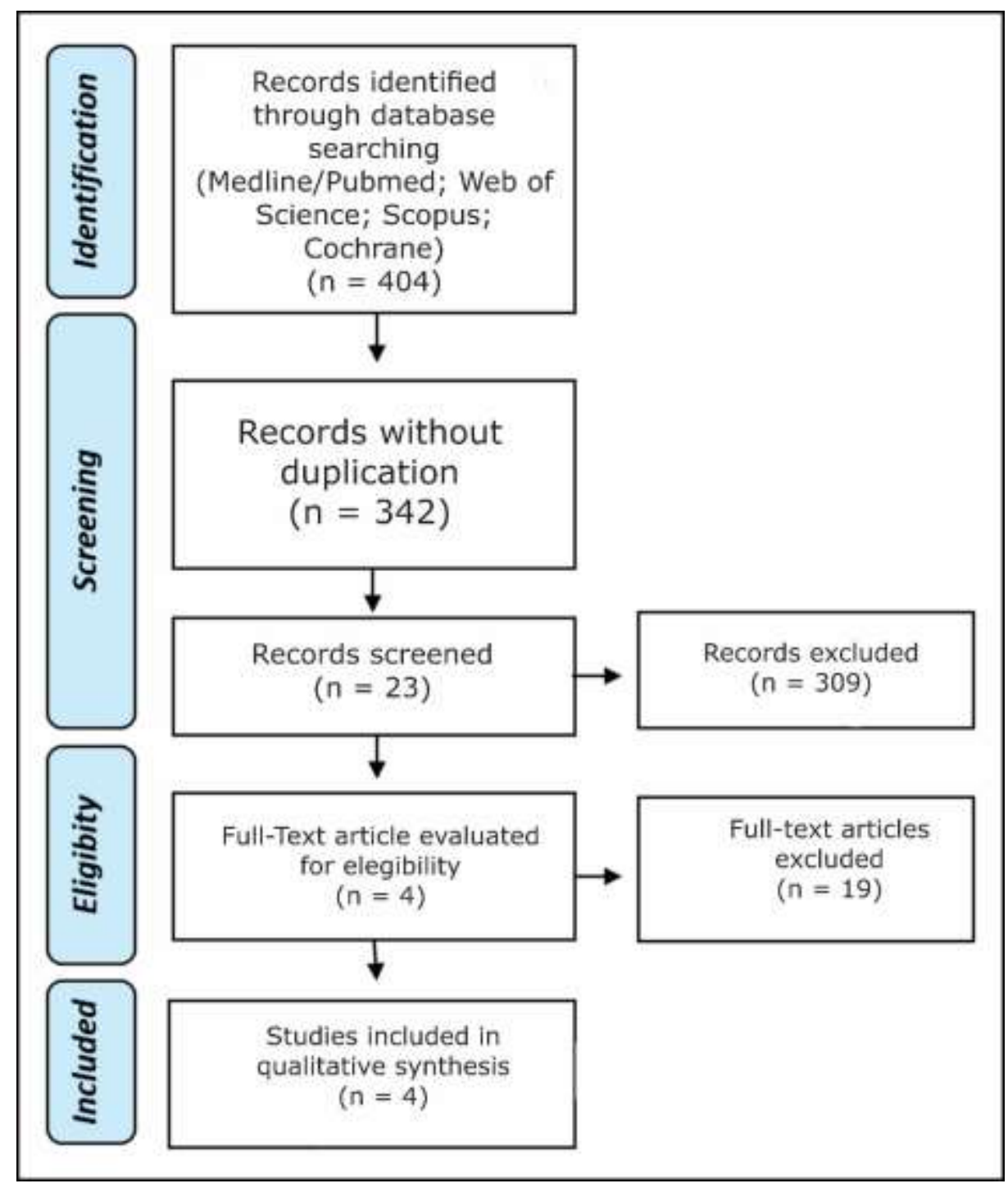

Source: Authors (2021).

\section{Criteria of inclusion and exclusion}

The works selected to be part of the review were randomized clinical trials, prospective and retrospective clinical trials in English and available on-line, with, at least, 10 pediatric patients. The elected studies had to present a sufficient data of the modalities of treatment of odontogenic cellulitis to allow a comparison between the surgical treatment (incision and drainage associated, or not, with tooth extraction or pulp treatment) and conservative treatment (just intravenous antibiotics associated, or not, with tooth extraction or pulp treatment).

\section{Level of evidence}

The studies were classified according to their level of evidence as proposed by the National Health and Medical Research Council to show their quality (Coleman et a., 2015). 


\section{Selection of the studies}

To select the titles, abstracts and full articles, a Kappa test was performed, independently, by two calibrated examiners (AHO and CAAL) resulting on concordance values of $\mathrm{k}=0.81$ for PubMed/MEDLINE, $\mathrm{k}=0.82$ for Web of Science, $\mathrm{k}=0.85$ for Scopus and $\mathrm{k}=1.0$ for Cochrane, according with the inclusion and exclusion criteria.

\section{Results}

\section{Search on literature}

The initial search for articles was conducted according to PICO and it was obtained 404 studies, which 277 were found on the database Pubmed/MEDLINE, 85 were found on Web of Science, 24 were found on the database "Scopus". 62 articles of this 404 was repeated, which was excluded resulting in 342 articles. After reading the summaries, 324 items were eliminated from the studies for not be found inside the inclusion and exclusion criteria, such as, language, clinical trials with less than 10 patients and case reports. After perusal of the 18 remaining studies it was excluded 14 more because it not provides adequate information or there was not a only pediatric patients study. Therefore, at the end of the search it was obtained 4 studies consistent with the theme (Table.1).

Table 1 - Profile of patients and analyzed articles.

\begin{tabular}{|c|c|c|c|c|c|c|}
\hline Author & Year & Patient & $\begin{array}{l}\text { Mean Age } \\
\text { (years) }\end{array}$ & Gender & $\begin{array}{l}\text { Level of } \\
\text { evidence }\end{array}$ & Kind of study \\
\hline Kara A et al. & 2013 & 106 & $7.28 \pm 3.26$ & $58.49 \%$ male & III-2 & Retrospective \\
\hline $\begin{array}{c}\text { Thikkurissy } \mathrm{S} \text { et } \\
\text { al. }\end{array}$ & 2010 & 63 & $8.3 \pm 3.8$ & $50.7 \%$ male & III-2 & Retrospective \\
\hline Rush DE et al. & 2007 & 60 & $\begin{array}{l}\text { Range: } 2-14 \\
\text { (NR mean) }\end{array}$ & $63.33 \%$ male & II & Prospective \\
\hline Lin YTJ et al. & 2006 & 56 & $5.72 \pm 2.7$ & $50 \%$ male & III-2 & Retrospective \\
\hline
\end{tabular}

Source: Authors (2021).

\section{Study characteristics}

Among the selected studies, we can observe their characteristics on Table 1, which were found three retrospectives studies (Kara et al., 2014; Lin et al., 2006; Thikkurissy et al., 2010) and one prospective study (Rush et al., 2007). The number of patients evaluated range from 30 to 106 and the range of age from 1 year and 1 month to 17 years-old. The studies bring pediatric patients presenting odontogenic cellulitis who undergone to conservative or drainage treatment. The variables presented by these articles and evaluated by this study were: Number of patient, mean age, gender, principal anatomic region affected, temperature on admission, kind of treatment, length of hospital stay, principal antibiotic intravenous elected, postoperative complication, complication during conservative treatment, recommended treatment by the study and kind of study. 


\section{Analysis of evidences of conservative treatment}

The studies presented a similar treatment choice tended to conservative treatment. The rate range of the conservative treatment of the evaluated studies was $75 \%$ to $95 \%$. The length of hospital stay mean range was $2.08 \pm 1.02$ to $5.86 \pm 3.38$ but it was not separate specifying the kind of treatment, although, Thikkurissy, S et al. related that the length of hospital stay have no significant difference between the conservative and surgical treatment (Thikkurissy et al., 2010). Besides of that, $75 \%$ of the authors recommended or preferred the conservative treatment. (Table 2)

\section{Analysis of evidences of drainage treatment}

There was a convergent result about the choice of treatment. The drainage was the option just for $4,8 \%$ to $25 \%$ of the cases. Thikkurissy et al. (2010) shown no complications associated to both of treatment, but most of the studies not related clearly this information. The drainage was the recommended option, where possible, to $25 \%$ of the authors. Rush et al. (2007) refer drainage in $15 \%$ of their patients, but at begin of the article, they explain that the incision and drainage were performed when "swelling was localized in one area and was fluctuant" what characterized an abscess, not cellulitis. On this way, we can affirm the author drained none of odontogenic cellulitis, just abscess. (Table 2)

Table 2 - Kind of treatment and variables associated with the infection

\begin{tabular}{|c|c|c|c|c|c|c|c|}
\hline \multirow{2}{*}{ Author } & \multirow{2}{*}{ Year } & \multicolumn{2}{|c|}{ Kind of Treatment } & \multirow{2}{*}{$\begin{array}{c}\text { Length of } \\
\text { Stay mean } \\
\text { (days) }\end{array}$} & \multirow{2}{*}{$\begin{array}{l}\text { Postoperative } \\
\text { complication }\end{array}$} & \multirow{2}{*}{$\begin{array}{c}\text { Complication } \\
\text { during conservative } \\
\text { treatment }\end{array}$} & \multirow{2}{*}{$\begin{array}{c}\text { Recommended } \\
\text { treatment by the } \\
\text { study }\end{array}$} \\
\hline & & Conservative & Drainage & & & & \\
\hline Kara et al. & 2013 & $90 \%$ & $10 \%$ & $5.86 \pm 3.38$ & NR & NR & Conservative \\
\hline $\begin{array}{c}\text { Thikkurissy et } \\
\text { al. }\end{array}$ & 2010 & $95.2 \%$ & $4.8 \%$ & $2.08 \pm 1.02$ & None & None & Conservative \\
\hline Rush et al. & 2007 & $85 \%$ & $15 \%$ & NR & NR & NR & Drainage \\
\hline Lin et al. & 2006 & $75 \%$ & $25 \%$ & $5.03 \pm 3.8$ & NR & NR & Conservative \\
\hline
\end{tabular}

Source: Authors (2021).

\section{Analysis of variables linking both treatments}

The affected area was a consonant data being more common in $75 \%$ of the studies in upper face. Upper and lower face infection, respectively, consist of the swelling located above or below the lip line, including all intra and extraoral regions. The most of the studies measure, on admission, a high temperature in patients. The fever rate range affected $14,28 \%\left(>37^{\circ} \mathrm{C}\right)$ to $38,67 \%\left(>38^{\circ} \mathrm{C}\right)$ of each study, meaning, $\mathrm{n}=8$ and $\mathrm{n}=41$ patients, respectively. The principal antibiotic elected was Clindamycin, being, in $50 \%$ of articles, the first choice and in $25 \%$ the second choice. The preferred second choice of antibiotic was Ampicillin associated with Sulbactan. (Table 3) 
Table 3 - Variables associated with the infection.

\begin{tabular}{|c|c|c|c|c|}
\hline Author & Year & $\begin{array}{l}\text { Main region } \\
\text { affected }\end{array}$ & $\begin{array}{l}\text { Temperature on } \\
\text { admission }\end{array}$ & Main intravenous antibiotic elected \\
\hline Kara et al. & 2013 & Upper face & $38,67 \%\left(>38^{\circ} \mathrm{C}\right)$ & $\begin{array}{l}\text { Ampicillin/sulbactan, ornidazole } \\
\text { (NR\%) }\end{array}$ \\
\hline Thikkurissy et al. & 2010 & Upper face & $\begin{array}{l}37.5^{\circ} \mathrm{C} \pm 0.8^{\circ} \mathrm{C} \\
\text { mean }(\mathrm{NR} \%)\end{array}$ & $\begin{array}{l}58.7 \% \text { Clindamycin , } 41.2 \% \\
\text { Ampicillin/sulbactan }\end{array}$ \\
\hline Rush et al. & 2007 & Lower face & NR & $\begin{array}{c}51.66 \% \text { Clindamycin , } 48.33 \% \\
\text { Ampicillin/sulbactan }\end{array}$ \\
\hline Lin et al. & 2006 & Upper face & $14,28 \%\left(>37^{\circ} \mathrm{C}\right)$ & Penicillin, Clindamycin (NR\%) \\
\hline
\end{tabular}

Source: Authors (2021).

\section{Discussion}

Despite being ostensibly studied in the literature, odontogenic cellulitis still no absolute consensus regarding its treatment, a fact that is amplified when pediatric patients are involved. In literature, there are authors who defend conservative treatment (Chow et al., 1978; Heimdahl \& Nord, 1983; Peterson, 2003; Shanti \& Aziz, 2011; Moose, 1968) and others who advocate for the surgical treatment of odontogenic cellulitis (Rush et al., 2007; Doležalová et al., 2015; Heimdahl et al., 1985; de-Vicente-Rodríguez, 2004).

The authors who defend conservative therapy claim that after the removal of the cause of the infection, antibiotic therapy should be performed and wait the evolution of odontogenic cellulitis to the stage of odontogenic abscess for the drainage or spontaneous resolution. Thus, the dieresis and surgical exploration of the anatomical planes to perform the drainage, when the infection is in the stage of cellulite, could promote the spread of infection both systemically and the surrounding anatomical planes (Chow et al., 1978; Heimdahl \& Nord, 1983; Peterson, 2003; Shanti \& Aziz, 2011; Moose, 1968).

Surgical treatment presumes that early drainage of the infection, even in the stage of odontogenic cellulitis, is the best treatment alternative, as it would avoid the accumulation of bacteria and secretions inside the tissues and, consequently, avoid the progression of the infection to deep spaces due to the drainage path created by the installed drain and recommended to drain as early as possible (Rush et al., 2007; Doležalová et al., 2015; Heimdahl et al., 1985; de-Vicente-Rodríguez, 2004).

Huang et al. (2004) evaluated 185 cases of deep neck infection (most of them due odontogenic cause) in adult patients of which 43 were diagnosed with cellulitis. Most of the cellulitis cases (40 patients) were treated by conservative treatment and only 2 patients treated by drainage. The author report only one complication associated to cellulitis treatment, who had internal jugular vein thrombosis, but didn't specify if it was in a patient underwent conservative treatment or drainage. It shown that the incision and drainage have not been the only way to treat cellulitis even in adults.

In pediatric patients, there are few studies about the treatment of odontogenic cellulitis and it generates some doubt for the clinician to face a dental infection in cellulitis stage. This doubt is not only for dentistry clinicians: 138 members of The 
American Society of Pediatric Otolaryngology were attempted and answered about how they treated retropharyngeal infections. When airway is not compromised, $62 \%$ of respondents routinely or occasionally institute a trial of intravenous antibiotics therapy before considering operative drainage. Fifty one percent of respondents say that unless $20 \%$ to $40 \%$ of their cases of retropharyngeal infections are resolve with antibiotic therapy alone. However, 22\% are of the opinion that antibiotics alone are never sufficient treatment (Lalakea \& Messner, 1999). In the light of this, for dentistry, it must be considered that the odontogenic cellulitis, in pediatric patients, is less systemically debilitating, inducing lower fever and white blood cell count (Unkel et al., 1997). At the present study, most of the authors adopted the conservative treatment ranging of $75 \%$ to $90 \%$ of all patients treated and most of them (75\%) recommend conservative treatment too. Lin et al. (2006) explain it, affirming that dental or surgical interventions can be delayed through the proper use of antibiotics because young children have a better response to antibiotics than adults.

The prior antibiotic elected was the Clindamycin by $50 \%$ of the authors, but the others first choice was penicillin and ampicillin/sulbactan showing good clinical response and in according to literature.15, 21, 22

Kara et al. (2014) showed the higher length of hospital stay and more patient with fever (and higher fever than the other studies) of all articles analyzed. These two variables can be associated once the fever may presume the higher virulence of infection and debility of patient, resulting in a higher length of hospital stay. On the other hand, it has not linked with the kind of treatment, once Thikkurissy et al. (2010), had the highest rate of conservative treatment choice, showed the lowest length of stay and concluded the surgical treatment versus just antibiotic treatment had no significant impact on these variables. Kara et al. (2014) evaluated 106 charts of pediatric patients presenting a conservative treatment in $90 \%$ of cases. Although there was not reported the complications of conservative treatment in the study, the author recognize what an appropriated conservative treatment may prevent redundant surgical intervention. On the other hand, this study, used as exclusion criteria, patients presenting preseptal and orbital cellulitis.

A limitation founded in this study is the difficult to diagnose correctly a cellulitis. Some authors confound cellulite with abscess and it turns into a difficult to select the aim studies.

A data that must be considered is the success and failures attempts to treat the cellulitis: one form of success of the conservative treatment (encapsulate the infection and turn it in an abscess) and the failure of the conservative treatment must be resolve with a drainage treatment. On this way, many of surgical treatment analyzed could be a fail or a successful conservative treatment and it could be in an advanced spread stage and low responsive to antibiotics or in a localized infection and easy to resolve with surgical drainage. Although, there is no reports about this in the studies analyzed. Another limitation found was the few number of studies evaluating the treatment of cellulitis in pediatric patients (only 4) and even the majority of found were retrospective studies. Thus, additional and standardized studies are necessary to get better clinical responses, avoiding the mentioned limitations above.

\section{Conclusion}

Despite all the limitations and necessity of more studies on the subject, the studies demonstrated that the conservative treatment of odontogenic cellulitis could be a feasible option to the pediatric patients.

\section{References}

Chow, A. W., Roser, S. M., \& Brady, F. A. (1978). Orofacial odontogenic infections. Ann Intern Med, 88:392.

Coleman, K., Norris, S., Weston, A., Grimmer-Sommers, K., Hillier, S., \& Merlin, T: 2015). NHMRC additional levels of evidence and grades for recommendations for developers of guidelines. http://www.nhmrc.gov.au/_files_nhmrc/file/guidelines/stage_2_consultation_levels_and_grades.pdf, 2015. 
Doležalová, H., Zemek, J., \& Tuček, L. (2015). Deep Neck infections of Odontogenic Origin and Their Clinical Significance. A Retrospective Study from Hradec Králové, Czech Republic. Acta Medica (Hradec Kralove), 58(3):86-91.

Gilmore, W. C., Jacobus, N. V., Gorbach, S. L., Doku, H. C., \& Tally, F. P. 1998. A prospective double-blind evaluation of penicillin versus clindamycin in the treatment of odontogenic infections. J Oral Maxillofac Surg, 46(12):1065-70.

Heimdahl, A., \& Nord, C. E. (1983). Orofacial infections of odontogenic origin. Scand J Infect Dis Suppl, 39:86.

Heimdahl, A., von Konow, L., Satoh, T., \& Nord, C. E. (1985). Clinical appearance of orofacial infections of odontogenic origin in relation to microbial findings. J Clin Microbiol, 22:299-302.

Huang, T. T., Liu, T. C., Chen, P. R., Tseng, F. Y., Yeh, T. H., \& Chen, Y. S. (2004). Deep neck infection: analysis of 185 cases. Head Neck, 26(10):854-60.

Kara, A., Ozsurekci, Y., Tekcicek, M., Karadag, Oncel, E., Cengiz, A. B., Karahan, S., Ceyhan, M., Celik, M. O., \& Ozkaya-Parlakay, A. (2014). Length of hospital stay and management of facial cellulitis of odontogenic origin in children. Pediatr Dent, 36(1):18E-22E.

Lalakea, M., \& Messner, A. H. (1999). Retropharyngeal abscess management in children: current practices. Otolar-yngol Head Neck Surg, 1999;121:398-405.

Lin, Y. T., \& Lu, P. W. (2006). Retrospective study of pediatric facial cellulitis of odontogenic origin. Pediatr Infect Dis J, 25:339-42.

Moghimi, M., Baart, J. A., Karagozoglu, K. H., \& Forouzanfar, T. (2013). Spread of odontogenic infections: a retrospective analysis and review of the literature. Quintessence Int, 44(4):351-61.

Moher, D., Liberati, A., Tetzlaff, J., \& Altman D. G. (2009). Group P: Preferred reporting items for systematic reviews and meta-analyses: the PRISMA statement. PLoS Med, 6:e1000097.

Moose, S. M. (1968). Acute infections of the oral cavity. In: Kruger GO, editor. Textbook of oral surgery. (3. ed.). St Louis (MO): CV Mosby Co, p. 166-90.

Ogle, O. E. (2017). Odontogenic Infections. Dent Clin North Am, 61(2):235-252.

Peterson, L. J. (2003). Principles of management and prevention of odontogenic infections. In: Peterson LJ, Ellis E, Hupp JR, et al, editors. Contemporary oral and maxillofacial surgery. 4th edition. St Louis (MO): Mosby. p. 344-66.

Prabhash, K., Bajpai, J., Gokarn, A., Arora, B., Kurkure, P. A., Medhekar, A., Kelkar, R., Biswas, S., Gupta, S., Naronha, V., Shetty, N., Goyel, G., \& Banavali, S. D. (2014). Comparison of isolates and antibiotic sensitivity pattern in pediatric and adult cancer patients; is it different? Indian J Cancer, 51(4):496-501.

Rush, D. E., Abdel-Haq, N., Zhu, J. F., Aamar, B., \& Malian, M. (2007). Clindamycin Versus Unasyn in the Treatment of Facial Cellulitis of Odontogenic Origin in Children. Clin Pediatr (Phila), 46(2):154-9.

Rush, D. E., Abdel-Haq, N., Zhu, J. F., Aamar, B., \& Malian, M. (2007). Clindamycin Versus Unasyn in the Treatment of Facial Cellulitis of Odontogenic Origin in Children. Clin Pediatr (Phila), 46(2):154-9.

Shanti, R. M., \& Aziz, S. R. (2011). Should we wait for development of an abscess before we perform incision and drainage? Oral Maxillofac Surg Clin North Am, 23(4):513-8.

Thikkurissy, S., Rawlins, J. T., Kumar, A., Evans, E., \& Casamassimo, P. S. (2010). Rapid treatment reduces hospitalization for pediatric patients with odontogenic-based cellulitis. Am J Emerg Med, 28(6):668-72.

Unkel, J. H., McKibben, D. H., Fenton, S. J., Nazif, M. M., Moursi, A., \& Schuit, K. (1997). Comparison of odontogenic and nonodontogenic facial cellulitis in a pediatric hospital population. Pediatr Dent, 19:476-9. 